\title{
TREŚCI I SYMBOLIKA POLICHROMII W KOŚCIELE CYSTERSÓW W JĘDRZEJOWIE (ZARYS PROBLEMATYKI)
}

Historia archiopactwa cystersów w Jędrzejowie sięga XII wieku, kiedy to, z inicjatywy braci Klemensa i Jana Gryfitów, sprowadzeni zostali do Polski pierwsi cystersi. Fundatorzy w latach 1141-1149 wznieśli i uposażyli dla nowo sprowadzonego zakonu klasztor w Jędrzejowie (dawniej Brzeźnicy). Klasztor ten stał się 21 filią opactwa w Marimond. W 1149 roku został podniesiony do godności opactwa. Równocześnie opactwo jędrzejowskie dało początek nowym fundacjom na ziemiach polskich - w Szczyrzycu i Rudach Wielkich ${ }^{1}$.

Pierwsza konsekracja kościoła klasztornego mała miejsce w 1166 roku $^{2}$, kolejna zaś - po rozbudowie i ukończeniu bazyliki w 1210 . Wówczas do patrona kościoła, św. Wojciecha, dodano drugie wezwanie: Wniebowzięcia Najświętszej Marii Panny. Przebudowa gotycka klasztoru i kościoła miała miejsce w 1475 roku, kiedy to ówczesny opat Mikołaj Odrowąż z Rembieszyc dokonał gruntownej modernizacji i gotycyzacji sprowadzając do prac nie tylko znanych architektów (Marcina z Jędrzejowa), ale i rzeźbiarzy (między innymi Wita Stwosza) czy złotników (Mikołaja Kreglera i Mikołaja Breimera). W wystroju kościoła jędrzejowskiego zaznaczył się także renesans i barok - glównie poprzez fundowanie nowych ołtarzy i płyt epitafijnych. W 1726 roku pożar w znacznej mierze zniszczył kościół i jego wyposażenie, jednak staraniem ówczesnego przeora o. Wojciecha

1 J. Mar e ck i, Zakony w Polsce, Kraków 2000, s. 30-31; W. K o l a k, J. M a r e c k i, Leksykon godel zakonnych, Łódź 1994, s. 58; B. Ło z in s k i, Leksykon zakonów w Polsce, Warszawa 1998, s. 41-42; Z. B i r k e n m a j e r, Ślaskie sprawy Gryfitów plockich XIII stulecia, Cieszyn 1938, s. 8-9; F. S i kora, Brzeźnica, [w:] Stownik historyczno-geograficzny województwa krakowskiego w średniowieczu , cz. I, Wrocław-Warszawa-Kraków 1985, s. 253-255; W. S e m k ow i c z, Nieznane nadania na rzecz opactwa jedrzejowskiego z XII wieku, „Kwartalnik Historyczny" R. 24:1910, s. 69-70; J. D o b o s z, Proces fundacyjny i pierwsze uposażenie opactwa cystersów w Jędrzejowie. [w:] Cystersi w Polsce. W 850-lecie fundacji opactwa jędrzejowskiego, red. D. Olszewski, Kielce 1990, s. 40-79; J. Z a w a d z k a, Proces fundowania opactw cysterskich w XII i XIII wieku, "Roczniki Humanistyczne” t. 7:1958, z. 2, s. 121-150; M. D a n i l u k, Z. Le szczyńsk i, Cystersi w Polsce, [w:] Encyklopedia katolicka, t. 3, Lublin 1995, kol. 726-733.

${ }^{2}$ Znawcy przedmiotu spierają się, czy była to pierwsza konsekracja, czy też wcześniej, przed przybyciem cystersów (1109-1181) miała miejsce konsekracja przeprowadzona przez biskupa Maurusa. Por. M. W rze s z c z, Jędrzejów, [w:] Encyklopedia Katolicka, t. 7, Lublin 1997, kol. 1455-1456; J. Z u b, Jędrzejów. Opactwo cystersów, Tarnobrzeg 2000, s. 5. 
Ziemnickiego na przestrzeni lat 1731-1741 kościół został odbudowany. W czasie tej odnowy, w latach 1734-1739, Andrzej Radwański wykonał monumentalną dekorację malarską światyni ${ }^{3}$.

Andrzej Radwański ${ }^{4}$ był jednym $\mathrm{z}$ niewielu artystów polskich XVIII wieku, którego życie i działalność artystyczną możemy w sposób możliwie precyzyjny i wiarygodny odtworzyć. Literatura dotycząca życia i twórczości Radwańskiego nie jest zbyt obszerna ${ }^{5}$, jednak zachowały się liczne archiwalia dokumentujące działalność malarza. Nade wszystko, ważnym dokumentem jest dziennik prowadzony przez samego artystę, w którym zapisywał informacje dotyczące zarówno prowadzonych przez niego prac, jak i życia prywatnego ${ }^{6}$.

Polichromia w kościele opackim w Jędrzejowie była pierwszą samodzielną i zarazem tak dużą realizacją młodego naówczas artysty. Radwański wykonał ją na okoliczność przygotowań do wyniesienia na ołtarze Wincentego Kadłubka (uzna-

${ }^{3}$ J. Z u b, Jędrzejów. Opactwo cystersów..., dz. cyt., s. 5-8; A. D u d e k, Jędrzejów. Archiopactwo cysterskie, Warszawa 1991, s. 42-46; J. P y z i e, Jędrzejów. Informator Archeologiczny, Warszawa 1991, passim; G. G l i ń s k i, Stan badań archeologiczno-architektonicznych klasztoru cystersów w Jędrzejowie, [w:] Cystersi. Misjonarze Europy, Kielce 1994, s. 85-99; B. K w i t k ow s ka-Kopka, W. Glińs k i, J. F i l e t, Najnowsze badania archeologiczne w obrębie opactwa ojców cystersów w Jędrzejowie, [w:] Klasztor w spoteczeństwie średniowiecznym i nowożytnym, red. M. Derwich, A. Pobóg-Lenartowicz, Opole-Wrocław, s. 539-545; R. G a r u s, Cysterskim szlakiem, Kielce 1998, s. 3-7; Monasticon Cisterciense Poloniae, red. A. M. Wyrwa, J. Strzelczyk, K. Kaczmarek, t. 2, Poznań 1999, s. 90-97.

${ }^{4}$ Andrzej Radwański urodził się 20 listopada 1711 roku w Białej koło Sulejowa jako jedyne dziecko Wojciecha i Marianny Radwańskich. Ojciec osierocił chłopca, gdy miał on 7 lat. Rok lub dwa lata później Andrzej rozpoczął naukę w miejscowej szkole, aby po trzech latach rozpoczą́ pracę jako pomocnik organisty w miejscowym kościele parafialnym. W 1723 roku Radwański rozpoczął naukę w kolegium księży Pijarów w Krakowie, równocześnie pracując w klasztorze i zakrystii kościoła pijarów. Pracą taką miał opłacić swój pobyt w kolegium. Dla ubogiej rodziny, pozbawionej stałych dochodów i majątku, był to jedyny sposób na kształcenie dziecka. W klasztorze Andrzej trafił na ks. Hieronima. W 1725 roku oddał on chłopca do bliżej nieznanego mistrza malarstwa, u którego Andrzej praktykował przez trzy miesiące. W jesieni 1727 roku przybył do Krakowa malarz Franciszek Eckstein, znany wówczas morawski twórca fresków. Szesnastoletni wówczas Andrzej zwrócił szybko na siebie uwagę mistrza. Najwyraźniej Eckstein dostrzegł spore możliwości artystyczne chłopca, ponieważ zaproponował pijarom zabranie go do Czech celem dalszego kształcenia. Radwański zobowiązany został do podpisania pisma, w którym zadeklarował chęć dalszego służenia pijarom. Zobowiązał się równocześnie do zrekompensowania $w$ przyszłości, pracą malarska, poniesionych przez nich kosztów na jego kształcenie. W Czechach Radwański pobierał nauki przez cztery lata. Po powrocie do Polski początkowo osiadł w Jędrzejowie, a następnie przeprowadził się do Krakowa, gdzie zmarł 11 września 1762 roku. Byl jednym z najplodniejszych krakewskich malarzy monumentalnych i sztalugowych 2. połowy XVIII wieku. Por. przypis 5.

${ }^{5}$ E. R a s t a w i e c k i, Stownik malarzy polskich, t. 2, Warszawa 1850, s. 122-124; A. G ra b ow s k i, Ojczyste spominki w pismach do dziejów dawnej Polski, t. 1, Kraków 1845, s. 255-265; A. A r t y m i a k, Mieszkańcy miasta Jędrzejowa w świetle najstarszej księgi metrykalnej 1743-1752, Jędrzejów 1947, s. 41-43; K. J ó ź k i e w i c z, Andrzej Radwański-malarz krakowski 1711-1762, „Biuletyn Krakowski” t. 3:1961, s. 160-200; Taż, Radwański Andrzej, [w:] Polski Slownik Biograficzny, t. 30/1, z. 124, Wrocław-Warszawa-Kraków 1987, s. 16-18.

${ }^{6}$ Archiwum Państwowe w Krakowie (cyt. APK), sygn. E 19, E 20, E 118, E 119, E 122, E 133, E 142, Teki Ambrożego Grabowskiego; Tamże, sygn. 476, Submissio Radwański R. Patribus Collegij Scholarum Piarum..., s. 2176-2177; Biblioteka Zakładu Narodowego im. Ossolińskich PAN we Wrocławiu, sygn. 5515-5536, Zbiór Gwalberta Pawlikowskiego. 
ny błogosławionym w 1764 roku) ${ }^{7}$. Malarz wykonał tę dekorację w dwóch etapach. Najpierw w latach 1734-1739 na zamówienie ówczesnego przeora (późniejszego opata) o. Wojciecha Ziemnickiego ${ }^{8}$, a następnie w roku 1754 , kiedy to uzupełnił polichromię kaplicy bl. Wincentego Kadłubka?

Głównym cyklem tematycznym monumentalnej dekoracji malarskiej świątyni opackiej w Jędrzejowie jest ukazanie historii i działalności zakonu cystersów. W sposób szczególny uwzględniona została postać pierwszego polskiego cystersa bł. Wincentego Kadłubka ${ }^{10}$. Cykl ten i rozmieszczenie poszczególnych scen opracował o. Wojciech Ziemnicki. Należy podkreślić jednak, że niewątpliwą zasługa Radwańskiego w procesie twórczym idei, jaka miała być przekazana poprzez dekoracje malarską świątyni, było wprawne przetworzenie myśli ojca Ziemnickiego na język sztuki i właściwe korzystanie z rad doświadczonego teologa.

Do naszych czasów polichromia zachowała się niemal w całości, choć wilgoć, pożary ${ }^{11}$ i uszkodzenia techniczne uszczupliły warstwę malarską szeregu kompozycji. Zachowane malowidła pokrywają powierzchnię sklepienia prezbiterium, nawy głównej i bocznej, transeptu, ścian bocznych nawy głównej oraz kaplicy bł. Wincentego Kadłubka ${ }^{12}$.

Kompozycje umieszczone na sklepieniu prezbiterium kościoła stanowią kwintesencję treści zawartych w całej polichromii kościoła. W trzech kolejnych przęsłach sklepienia artysta umieścił wynikające z siebie kompozycje. W części usytuowanej najbliżej ołtarza widać wyobrażenie opactwa jędrzejowskiego widocznego zza antycznej bramy. Brama ta ma zapewne symbolizować bramę niebieska, poprzez którą widać ziemię. Sugerują to kompozycje w następnych dwóch przęsłach - przedstawiają bowiem sceny dziejące się już w sferze niebieskiej. W kolejnym przęśle umieszczona została apoteoza bł. Wincentego Kadłubka unoszonego przez anioły wprost z opactwa jędrzejowskiego przez bramę niebieska ku chwale nieba. Kolejna kompozycja pokazuje natomiast chwałę całego zakonu cystersów oraz Matkę Bożą polecającą swojemu Synowi cały zakon. Aby sprawić wrażenie przestrzeni, Radwański umieścił na ścianach, ulubiony swój motyw iluzjonistycznie namalowanych okien.

${ }^{7}$ S. M a r c h e w k a, Btogostawiony Wincenty Kadtubek biskup $i$ wyznawca, patron Polski, Kraków 1917, s. 16-17; D. O I s zew s k i, Kult bl. Wincentego Kadlubka w Jędrzejowie. Zarys historii, [w:] Cystersi w Polsce. W 850-lecie fundacji opactwa jędrzejowskiego, red. D. Olszewski, Kielce 1990, s. 151-178.

${ }^{8}$ APK, sygn. E 122, Teka Ambrożego Grabowskiego, dz. cyt., s. 973.

${ }^{9}$ A. D u d e k, Jędrzejów. Archiopactwo cysterskie..., dz. cyt., s. 79.

${ }^{10}$ Wincenty Kadłubek - w latach 1208-1218 był biskupem krakowskim. W 1218 roku zrzekł się tej funkcji oraz godności i wstapił do klasztoru cystersów w Jędrzejowie, gdzie przebywał do końca życia. Jest autorem Kroniki Polski. Beatyfikowany w 1764 roku. Por. S. M a r chewka, Btogoslawiony Wincenty Kadlubek, biskup i wyznawca, patron Polski, Kraków 1917, passim; J. Stablińsk a, Mistrz Wincenty, Kraków 1973; K. Bukowski, Słownik polskich Swiętych, Kraków 1995, s. 142-143; K. S w i ż e k, Blogostawiony Wincenty Kadłubek, [w:] Polscy Święci, red. J. R. Bar, t. 2, Warszawa 1983, s. 11-62; Gwiazdy katolickiej Polski. Zywoty wielkich Stug Bożych, red. K. Wilk, Mikołów 1938, s. 74-84.

${ }^{11}$ Kolejne pożary miały miejsce w latach 1800,1914 . Por. A. Du de k, Jęrzejów. Archiopactwo cysterskie, Warszawa 1991, s. 31, 46-47

${ }^{12}$ Monasticon Cisterciense Poloniae..., dz. cyt., s. 96; K. J óź k i e w i cz, Andrzej Radwański..., dz. cyt., s. 168-173. 
Freski na sklepieniu transeptu są pewną kontynuacją treści przekazywanych przez malowidła prezbiterium. W miejscu przecięcia transeptu i nawy Radwański umieścił iluzjonistyczną kopułę przywodzącą na myśl wzór kopuły, jaki Andrea Pozzo ${ }^{13}$ nakreślił zarówno w swoim traktacie o malarstwie, jak również na wykonanych przez siebie polichromiach ${ }^{14}$. We wnętrzu copula falsa namalowanej przez Radwańskiego widnieją postacie Chrystusa i Maryi obdarzających laskami cystersów. Równocześnie zobrazowane zostały tu mistyczne zaślubiny zakonu z Maryją i Jezusem. Poniżej malarz umieścił św. Bernarda z Clairvaux oraz pierwszych opatów opactwa Citeaux. W narożach tej sceny widnieją cztery popiersia ewangelistów umieszczone w owalnych medalionach. To także często wykorzystywany przez Andrzeja Radwańskiego motyw ${ }^{15}$. Pozostałe części sklepienia transeptu zajmują alegoryczne postacie symbolizujące cztery kontynenty. Jest to podkreślenie zasług cystersów dla Kościoła poprzez pokazanie prowadzonych przez nich misji na czterech kontynentach. Kompozycja odnosząca się do działalności cystersów w Europie zwraca także uwagę na działalność kontrreformatorska zakonu ${ }^{16}$.

Kolejny wątek treściowy umieszczony został na sklepieniu nawy głównej świątyni jędrzejowskiej. Pomimo tego że freski sklepienne zostały mocno uszkodzone podczas działań wojennych w roku 1914 oraz w 1945, można odczytać przedstawione na nich sceny. Jest to cykl kompozycji obrazujących kolejne opactwa, powstające $z$ fundacji pramacierzystego klasztoru w Citeaux. I tak, w kolejnych przęsłach (licząc od prezbiterium) zobaczyć można fragmenty dawnego alegorycznego przedstawienia opactwa Firmitas ${ }^{17}$. Dalej opactwo Clairvaux, na tle którego artysta umieścił postacie papieża Innocentego $\mathrm{II}^{18}$ oraz św. Bernarda opata z Clairvaux ${ }^{19}$. Kolejne opactwo to Pontigny w Szampanii (istniejące $w$ latach

${ }^{13}$ Pozza Andrea (1642-1709) - jezuita, malarz, freskant, architekt, matematyk, teoretyk sztuki. Por. J. Kow a l c z y k, Andrea Pozzo a późny barok w Polsce, „Biuletyn Historii Sztuki" t. 37:1975, nr 2, s. 162-178; T e n ż e, Andrea Pozzo a póżny barok w Polsce, cz. II Freski sklepienne, „Biuletyn Historii Sztuki” t. 37: 1975, nr 3, s. 335-350.

${ }^{14} \mathrm{M}$. W it w i ń k a, Topografia $i$ kierunk malarstwa ściennego $w$ Polsce okolo polowy XVIII wieku, „Biuletyn Historii Sztuki” t. 43:1981, nr 1, s. 185; J. Kowalczyk, Andrea Pozzo a późny barok w Polsce. cz. II ..., s. 335-349.

15 Podobny motyw dekoracyjny wykorzystał Radwański w kościele w Staniątkach, u Wizytek w Krakowie oraz w zakrystii kościoła Mariackiego w Krakowie. Por. L. Rotter, Kościót i klasztor Wizytek w Krakowie, msp w posiadaniu Autorki; T a ż, Symbolika polichromii kościola pod wezwaniem św. Wojciecha i Najświętszej Marii Panny w Staniq̨tkach (msp złożony do druku ukaże się w 2004 roku); P. P e n c a k o w s k i, Dekoracja sklepienia zakrystii kościota mariackiego w Krakowie - refleks rzymskich malowidet Pietro da Cortona, „Folia Historiae Artium" t. 30:1994, s. 99-118.

${ }^{16}$ I Z z b, Jedrzejów Opactwo cystersów..., dz cyt, s. 20 21; A. Du d ck, Jędrzejótw Archiopactwo cysterskie..., dz. cyt., s. 76-77.

${ }^{17}$ La Ferte w Burgundii.

18 Jego pontyfikat (1130-1143) przypadł na burzliwe czasy walki z antypapieżem Anakletą II. Poprzez nieudane pociagnięcia polityczne uwikłał się w szereg konfliktów, między innymi z Lotarem III i Rogerem II. Popierany przez Bernarda z Clairvaux. Zainicjował Sobór Laterański II. Por. K. Dopierała, Księga papieży, Poznań 1996, s. 169-171; H. S t a d l e r, Leksykon papieży i soborów, Warszawa 1992, s. 98-99; L. B o ń c z a - B y s t r z y c k i, Innocenty II, [w:] Encyklopedia katolicka, Lublin 1997, t. 7, kol. 249.

19 Bernard z Clairvaux w 1112 roku, wraz z 30 towarzyszami, wstąpił do cystersów w Citeaux. Na czele 12 braci wysłany został do nowo założonej placówki w Clairvaux. Dzięki jego koligacjom rodzinnym zakon cystersów rozrósł się szybko na terenie Francji. Przyczynił 
1114-1791), zaś w ostatnim przęśle widać budowle opactwa Morimond w Szampanii (istniejące w latach 1115-1791) ${ }^{20}$.

Uzupełnieniem treści zawartych na kolejnych przęsłach sklepienia są kompozycje namalowane w strefie arkadowej. Malowidła te przedstawiaja postacie wybitnych cystersów oraz osób zasłużonych dla ich zakonu. I tak pierwszemu opactwu odpowiadają postacie papieży: bł. Eugeniusza $\mathrm{III}^{21}$ oraz Urbana $\mathrm{IV}^{22}$. Wokół drugiego przęsła rozmieszczone zostały postacie papieża Aleksandra III ${ }^{23}$ i papieża Benedykta XII ${ }^{24}$. Trzeciemu przęsłu odpowiadają wyobrażenia bł. Bernarda kardynała ${ }^{25}$ oraz naprzeciw św. Hugo kardynała ${ }^{26}$. Przy ostatnim przęśle Radwański umieścił św. Wilhelma arcybiskupa ${ }^{27}$ i św. Malachiasza arcybiskupa ${ }^{28}$.

się do powstania 300 nowych fundacji. Popierał w sporze Innocentego II. Kanonizowany w 1178 roku przez papieża Aleksandra III, ogłoszony doktorem Kościoła w 1830 przez papieża Piusa VIII. Por. H. F ro s, F. S o w a, Księga imion $i$ świętych, t. 1, Kraków 1997, kol. 430-434; D. A t $t$ w a t e r, C. R. J o h n, Dykcjonarz Świętych, Wrocław-Warszawa-Kraków 1997, s. 73-74; W. Z a le 5 ki, Święci na każdy dzień, Warszawa 2001, s. 485-488; S. K ę d zi or a, J. M i s i u r e k, Bernard z Clairvaux, [w:] Encyklopedia katolicka, Lublin 1995, t. 2, kol. 301-302; S. K i e 1 t y k a, Swięty Bernard z Clairvaux, Kraków 1983.

${ }^{20} \mathrm{~J}$. M a r e c k i, Zakony w Polsce..., dz. cyt., s. 30-31; B. Ło z i ń s k i, Leksykon zakonów..., dz. cyt., s. 41-42; M. D a n i l u k, S. K i e t t y k a, Cystersi, [w:] Encyklopedia katolicka, t. 3, Lublin 1995, kol. 721-726; J. K ł o c z ow s k i, Wspólnoty chrześcijańskie. Grupy życia wspólnego w chrzescijaństwie zachodnim od starożytnosci do XV wieku, Kraków 1964, s. 210 -224 .

${ }^{21}$ Eugeniusz III - zm. 1153. Cysters z Clairvaux, papiez, uczeń św. Bernarda. Por. H. Fro s, F. S ow a, Księga imion..., t. 2, kol. 214-215; K. D o p i e r ał a, Księga papieży..., dz. cyt., s. 175-180; M. Z a hajk i ew i c z, Eugeniusz III. [w:] Encyklopedia katolicka, Lublin 1995, t. 4, kol. 1294; H. S t a d l e r, Leksykon papieży..., dz. cyt., s. 56.

${ }^{22}$ Urban IV - zm. 1264. Był kanonikiem w Laon, uczestniczył w Soborze Lyońskim I. Jako legat papieski odbył w 1247 roku podróż do Polski. Wprowadził święto Bożego Ciała. Por. K. D o p i e r ał a, Księga papieży..., dz. cyt., s. 209-211; H. Stadler, Leksykon papieży..., dz. cyt., s. $298-299$.

${ }^{23}$ Aleksander III - zm. 118I. Wybitny prawnik i uczony. Zwołał Sobór Laterański III, gdzie sprecyzowano zasady wyboru papieża. Za jego pontyfikatu doszło do rozłamu i wyboru antypapieża. Z 23 lat pontyfikatu - 20 spędził poza Rzymem. Por. K. D o p i e r ał a, Księga papieży..., dz. cyt., s. 180-183; C. B a r o n, Aleksander III, [w:] Encyklopedia katolicka, Lublin 1995, t. 1, kol. 325-326; H. S t a d le r, Leksykon papieży.., dz. cyt., s. 16-18; A. Petrani, W sprawie dekretu papieża Aleksandra III, „Adivimus", „Roczniki Teologiczno-Kanoniczne” t. $16: 1969$, z. 5 , s. $5-10$.

${ }^{24}$ Benedykt XII - zm. 1342. Cysters, opat w Fontfroid, pełnił kolejno funkcję biskupa w Pamiers i kardynała, reformator kurii rzymskiej i zakonów benedyktyńskich. Por. K. K u źm i a k, Benedykt XII, [w:] Encyklopedia katolicka, Lublin 1995, t. 2, kol. 221-222; H. S t a d l e r, Leksykon papiezy..., dz. cyt., s. 34-35; H. F ro s, F. S o w a, Księga imion..., dz. cyt., t. 1, kol. 405-406; K. D o p i e r a ł a, Księga papieży..., dz. cyt., s. 242-245.

${ }^{25}$ Bernard - zm. 1170. Cysters z Clairvaux. Por. A. D u d e k, Jędrzejów. Archiopactwo..., dz. cyt., s. 75 .

${ }^{26}$ Hugo - zm. 1194. Cysters, opat w Bonnevaux. Por. A. M. Z i mmerman, Hugo v. Bonnevaux, [w: Lexikon für Theologie und Kirche, t. 5, Freiburg in Breisgau 1960, kol. 511.

${ }^{27}$ Wilhelm von Donjeon - ur. ok. 1150, zm. 1209. Cysters, prawnik, opat w Burges. Por. A. Emme n, Wilhelm v. Burges, [w:] Lexikon für Theologie und Kirche, t. 10, Freiburg in Breisgau 1985, kol. 1130.

${ }^{28}$ Malachiasz - zm. 1148. Biskup Connor i Down i legat papieski w Irlandii, założyciel licznych opactw i zakonów na terenie Irlandii. Por. W. Z a le s k i, Święci na każdy..., dz. cyt., 
Zauważyć trzeba, że postacie te ułożone zostały parami. Licząc od prezbiterium cztery przedstawienia papieży, następnie w trzecim przęśle dwóch kardynałów i wreszcie bezpośrednio nad chórem dwóch arcybiskupów.

Cykl postaci zasłużonych dla zakonu kontynuowany jest na ścianach transeptu. Wyobrażone zostały tam postacie św. Teresy królowej Portugalii ${ }^{29}$, bł. Konrada kardynala ${ }^{30}$ oraz Eryka króla duńskiego ${ }^{31}$.

Elementem łączącym treści dotyczące zasług zakonu oraz samego opactwa jędrzejowskiego są malowidła w nawach bocznych. Pokazują one sceny związane $z$ bł. Wincentym Kadłubkiem. Freski w nawie południowej uległy niemal całkowitemu zniszczeniu, natomiast w zachowanej polichromii nawy północnej wszystkie kompozycje dotyczą życia, działalności i cudów dokonanych przez błogosławionego cystersa. Zobaczyć więc można kompozycje przedstawiające Kadłubka odwożącego Salomeę na Węgry, zaślubiny Salomei z Kolomanem, Wincentego Kadłubka jako darczyńcę klasztorów i kościołów krakowskich oraz cuda błogosławionego - ożywienie zmarłego dziecka i ugaszenie pożaru w Chęcinach. Kontynuację tego tematu odnaleźć można w polichromii kaplicy bł. Wincentego Kadłubka, która przylega do północnej nawy kościoła ${ }^{32}$.

Polichromia kościoła opackiego w Jędrzejowie jest, jak wspomniano, pierwszą monumentalną realizacją Andrzeja Radwańskiego. Jednak już tutaj można zauważyć, że tworzył on kompozycje głęboko przemyślane, poparte wnikliwymi studiami i mające na celu nie tylko ozdabiać wnętrze, ale również nieść ze soba głębokie treści. Jego prace poprzedzone były zawsze głęboką analizą i indywidualnym podejściem do miejsc, w których dane mu było tworzyć.

W świątyniach wspólnot zakonnych staral się przekazać poprzez sztukę duchowość i historię zakonu ${ }^{33}$. W polichromii jędrzejowskiej dominuje właściwie tylko jeden watek treściowy - Chwała Zakonu i tamtejszego opactwa. W polichromiach wykonanych dla benedyktynów w Tyńcu i wizytek w Krakowie Radwański także skupił się tylko na jednym cyklu tematycznym, jakim było ukazanie życia i apoteozy świętych założycieli zakonów - w pierwszym przypadku św. Benedykta i św. Scholastyki, zaś w drugim - św. Franciszka Salezego i św. Joanny Franciszki de Chantal. Najbardziej skomplikowaną myśl ideową zawarł natomiast w ostatnim swoim dziele, jakim była polichromia w Staniątkach. Przekazuje ona bowiem zarówno treści teologiczne jak i mariologiczne, ale też w sposób całościowy i przemyślany pokazuje tak zwaną Chwałe Zakonu, a wszystkie te cykle

s. 691-692; D. A ttwater, C. R. Joh n, Dykcjonarz Swiętych..., dz. cyt., s. 271-272; H. F ro s, F. S ow a, Ksiega imion..., dz. cyt., t. 4, kol. 47-49.

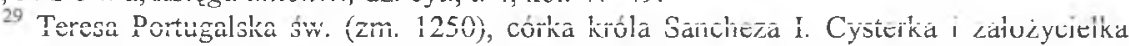
opactwa cysterek w Lorvao. H. F r o s, Martyrologium czyli wspomnienia świętych przypadajace na poszczególne dni roku, Warszawa 1984, s. 126.

${ }^{30}$ Konrad von Urach (1177/1780-1227), opat w Clairvaux i Citeaux, kardynat, legat papieski. B. Gri e s s e r, Konrad v. Urach. [w:] Lexikon für Theologie und Kirche, t. 6, Freiburg in Breisgau 1961, kol. 474.

${ }^{31}$ Eryk - koronowany w 1232 roku. Zamordowany w 1250 roku w czasie bratobójczych walk przez swojego brata Abla. M. Z a h a j k i ew i c z, Eryk IV, [w:] Encyklopedia katolicka, Lublin 1995, t. 4, kol. 1102; H. F r o s, F. S o w a, Księga imion..., dz. cyt., t. 1, kol. 190-191.

${ }^{32}$ A. D u de k, Jędrzejów. Archiopactwo..., dz. cyt., s. 77, 79-80.

${ }^{33} \mathrm{Na}$ umiejętność właściwego rozumienia duchowości zakonnej przez Radwańskiego, miała niewątpliwie wpływ jego nauka w szkole i pobyt w kolegium księży pijarów w Krakowie. 
łączy ze sobą w jeden ciąg myślowy odnoszący się do Bożego Planu Zbawienia Czlowieka ${ }^{34}$.

W odniesieniu do wymienionych i przekazywanych przez dzieła Radwańskiego treści można w jego twórczości wyodrębnić pewne wątki tematyczne powtarzajace się we wszystkich przez niego wykonanych polichromiach.

W każdym kościele klasztornym, który malarz ozdabiał, jedno z najistotniejszych miejsc zajmowały sceny związane z przedstawieniem apoteozy założyciela zakonu lub świętego związanego z konkretnym konwentem. Przedstawienia takie związane były nie tylko $z$ propagowaniem duchowości danego zakonu, ale także z charakterystycznym dla XVIII wieku zainteresowaniem hagiografią i historią w tym wypadku hagiografią i historią własnego zakonu. Częstym tematem jest także motyw związany z Niepokalanym Poczęciem oraz podkreślający znaczenie i triumf Kościoła katolickiego. Te ostatnie tematy narzucała niejako „potrzeba chwili" i proces kontrreformacji, w który żywo zaangażowana została także sztuka.

Oprócz oczywistych przedstawień związanych z założycielami poszczególnych zakonów częstym motywem wykorzystywanym przez malarza były portrety papieży - najczęściej związanych pochodzeniem lub zasługami $z$ konkretną wspólnotą zakonną. Inny podejmowany temat stanowiły wyobrażenia fundatorów kościołów zakonnych oraz świętych związanych z ozdabianymi przez Radwańskiego świątyniami.

Istotnym elementem składowym polichromii autorstwa Andrzeja Radwańskiego była symbolika. Zgodnie z duchem barokowej kultury i sztuki umieszczał w swoich kompozycjach treści ze sfery duchowej, które przybierały formę symboli lub emblematów.

Najczęściej stosowanym przez malarza środkiem przekazu symbolicznego były personifikacje. W Jędrzejowie są to personifikacje czterech kontynentów widniejące $w$ transepcie świątyni klasztornej. Na malowidłach ściennych w opactwie staniąteckim odnaleźć można postacie ośmiu błogosławieństw oraz trzech cnót. W opactwie w Tyńcu zachowały się wyobrażenia cnót umieszczone poniżej kopuł w kaplicach bocznych światyni. Wszystkie personifikacje to postacie kobiet opatrzone odpowiednimi symbolami, dzięki którym kompozycje nabierają odpowiedniego znaczenia. Do personifikacji zaliczyć można także postać Eklezji na sklepieniu nawy głównej kościoła w Staniątkach ${ }^{35}$.

Innymi stosowanymi przez Andrzeja Radwańskiego symbolami są emblematy. Wykorzystywanie ich $\mathrm{w}$ polichromiach zauważyć można jednak dopiero w ostatnich dwóch realizacjach - w świątyni wizytek w Krakowie i w opactwie benedyktyńskim w Staniątkach. Ze względu na zniszczenia polichromii trudno kategorycznie stwierdzić, czy malarz nie używał podobnej symboliki również w innych swoich dziełach.

Do przedstawień symbolicznych można zaliczyć także kompozycje malarskie $z$ kaplicy św. Benedykta w Tyńcu, wyobrażające cudowne działanie medalika św. Benedykta. Jest to jednak pojedyncze przedstawienie, które - mimo realizo-

\footnotetext{
${ }^{34}$ L. R o t t e r, Symbolika polichromii kościoła..., op. cit.

${ }^{35} \mathrm{G}$. B e refelt, O symbolu $i$ alegorii, [w:] Archiwum thmaczen z teorii literatury i metodologii badań literackich, z. 5, Lublin 1982, s. 51-62.
} 
wania podobnych polichromii w innych kościołach Reguły benedyktyńskiej - nigdzie więcej nie występuje ${ }^{36}$.

$\mathrm{Na}$ koniec warto nakreślić kilka uwag dotyczących walorów artystycznych polichromii Andrzeja Radwańskiego. Krystyna Jóźkiewicz wskazuje, że na twórczość artystyczną malarza miały wpływ trzy elementy: iluzjonizm Franciszka Ecksteina, eklektyzm włoski Szymona Czechowicza oraz sarmackie malarstwo portretowe $^{37}$. Właściwie można przyjąc taką teorię, nietrudno bowiem doszukać się w twórczości Radwańskiego tych właśnie elementów.

Przyswojone sobie w czasie czteroletniego pobytu w Czechach zasady malarstwa iluzjonistycznego Andrzej Radwański stosował w sposób dość ograniczony. Zapewne miały na to wpływ ramy architektoniczne w kościołach, w których realizował swoje polichromie. Niemniej faktem jest, że założenia iluzjonistyczne stosował dość oszczędnie. Jedyne zastosowanie copula falsa zobaczyć można w kościele jędrzejowskim, iluzjonistyczne fragmenty architektoniczne natomiast (oprócz wymienionego kościoła) także w Staniątkach. Do tegoż gatunku zaliczyć można również motyw otwartego nieba, jaki wykorzystał malarz w mniej lub bar dziej ograniczony sposób we wszystkich znanych nam dzisiaj polichromiach. Natomiast wyraźnie ulubionym motywem artysty były iluzjonistyczne okna, kartusze i medaliony.

Malarstwo Andrzeja Radwańskiego pod względem artystycznym uważane jest za niezbyt wyszukane i mocno trzymające się rodzimych wzorców i tradycji. Jednak niezaprzeczalną wartością jego polichromii jest przekazywana przez dzieło sztuki treść, głęboko przemyślana i umiejętnie przedstawiona.

Już od czasów średniowiecza dekoracje malarskie i programy ikonograficzne dzieł sztuki były efektem współpracy artysty z teologiem. W okresie baroku monumentalne dekoracje świątyń obejmujące swym zasięgiem i zarazem łącaace w sobie polichromię, formę ołtarzy i pozostałego wyposażenia kościola zmuszały artystów do takiej współpracy. Istotne bowiem było, aby forma artystyczna we właściwy sposób przekazywała skomplikowane nieraz treści duchowe. Konsekwencja i jednolity program ikonograficzno-symboliczy, jaki można zaobserwować w wielu kościołach posiadajacych osiemnastowieczny wystrój, wydaje się być potwierdzeniem hipotezy o takiej artystyczno-teologicznej współpracy, czego przykładem jest również dekoracja malarska kościoła Cystersów w Jędrzejowie realizacja pozwalająca obecnie badaczom na wnikliwe poznawanie bogatych symboli i znaczeń, które odzwierciedlają historię chrześcijaństwa.

${ }^{36}$ A. W ł o d a r e k, Dekoracja malarska kaplicy św. Benedykta w Tyncu, msp w bibliotece Opactwa Benedyktynów w Tyńcu, passim; L. R o t t e r, Symbolika polichromii kościola..., dz. cyt.

${ }^{37}$ K. Jóź k i e w i c z, Andrzej Radwański..., dz. cyt., s. 197-198. 


\section{Content and Symbolics of Polychromy in Cistercian Church in Jędrzejów (outline of issues) \\ Summary}

A close theological and artistic co-operation has been observed in religious art since the Middle Ages. In the Baroque this co-operation was best revealed in monumental decorations inside churches. An example of it is the polychromy in the abbot church in Jedrzejów, whose author was Andrzej Radwański. Intention plan includes both theological content and issues connected with spirituality and activity of the Cistercian order. The history of the Jędrzejów Abbey was particularly emphasized and so was the person of the Blessed Wincenty Kadlubek, who was connected with it. A correlation between historical and symbolical depictions is very interesting; a method often used by Radwański in his monumental decorative painting. 


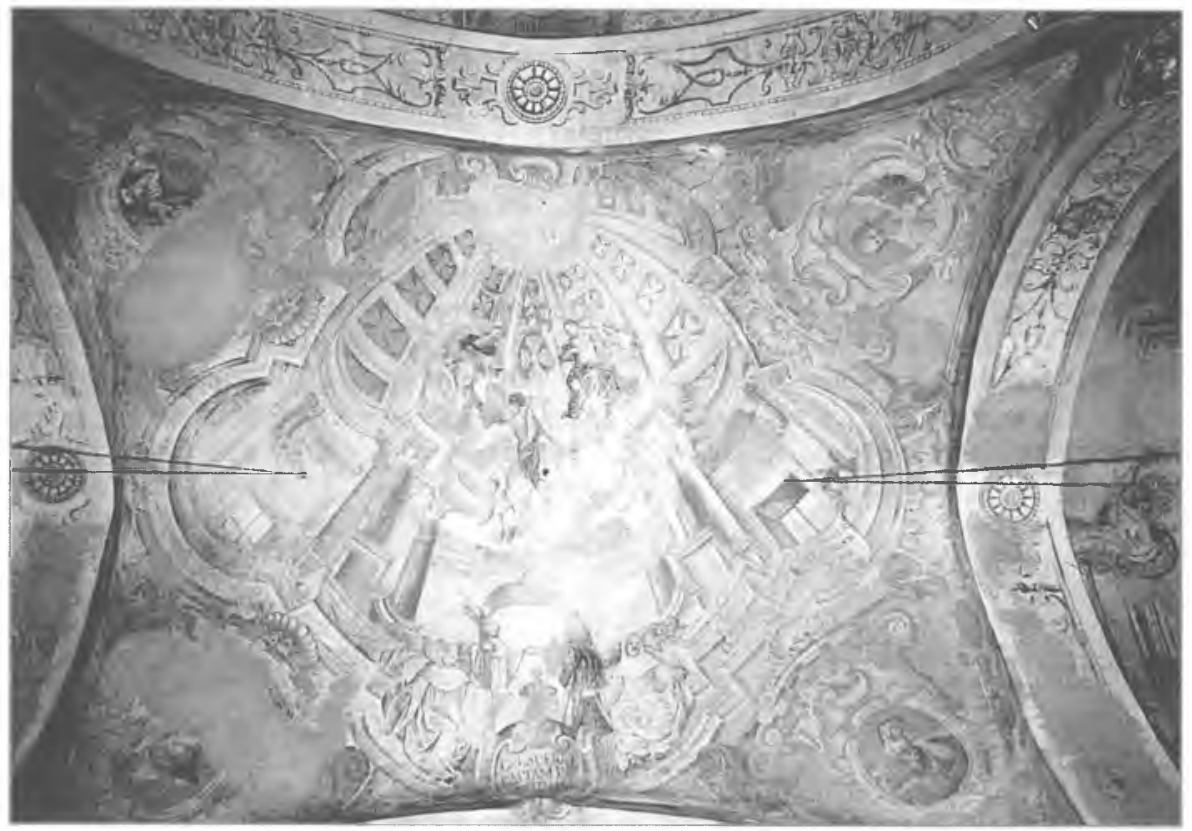

1. Apoteoza cystersów, sklepienie nawy głównej.

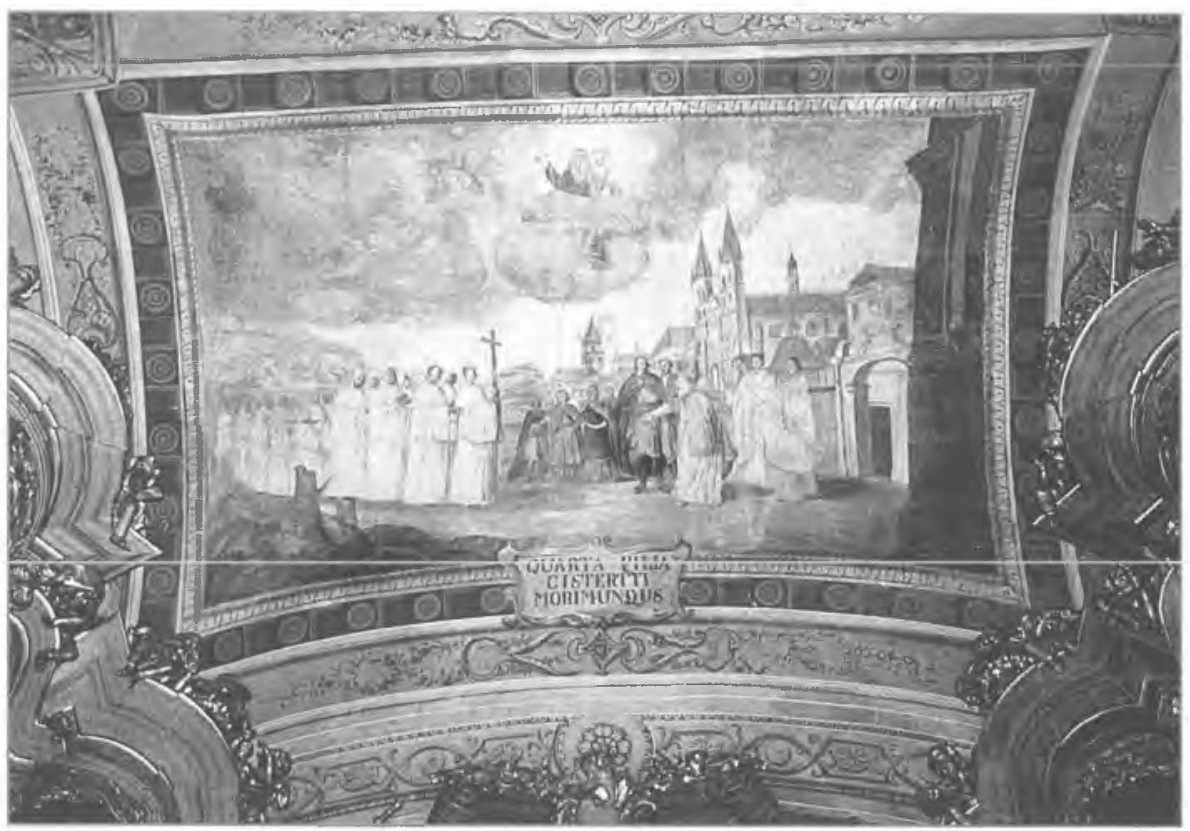

2. Fundacja Morimond, sklepienie nawy głównej. 


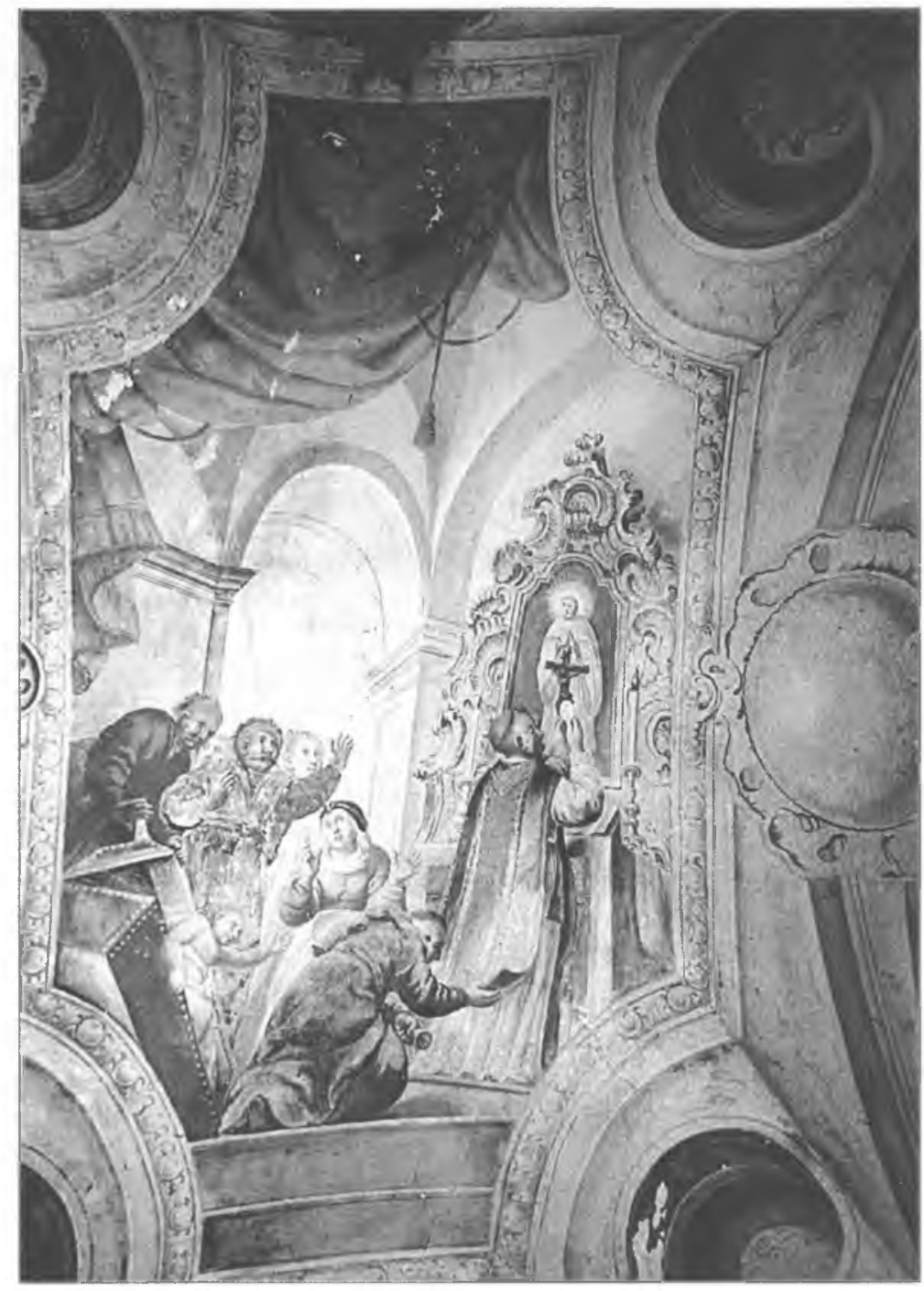

3. Cuda błogosławionego W. Kadłubka, sklepienie nawy bocznej. 


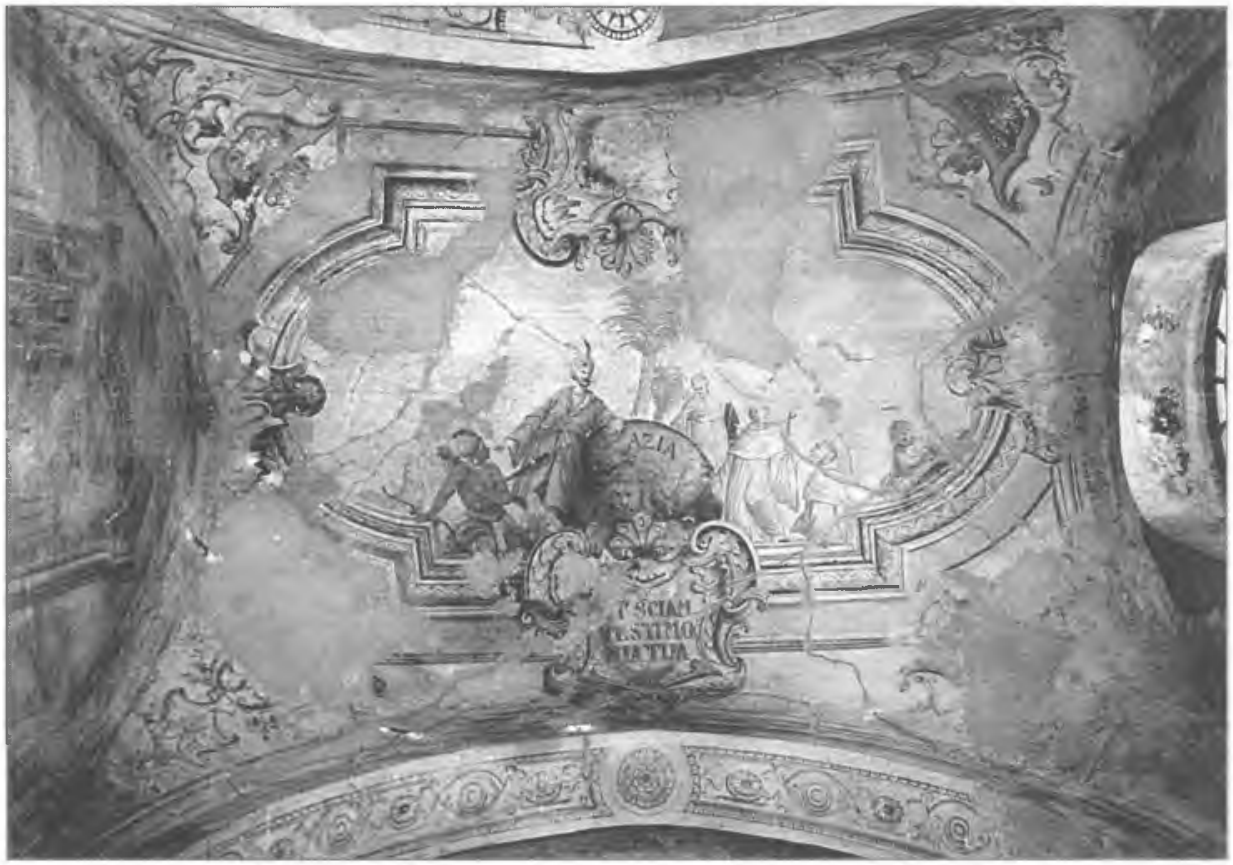

4. Alegoria Azji, sklepienie franseptu. 